\title{
Magnolia sulawesiana described, and a key to the species of Magnolia (Magnoliaceae) occurring in Sulawesi
}

\author{
F. Brambach ${ }^{1}$, H.P. Nooteboom², H. Culmsee ${ }^{3}$
}

Key words

Elmerrillia

Lore Lindu National Park

Magnolia

Magnoliaceae

Sulawesi

\begin{abstract}
Magnolia sulawesiana is described as new species and a modified key of Magnolia subsect. Elmerrillia is included. In addition, a new key of the ten Magnolia species occurring in Sulawesi is provided based on vegetative
\end{abstract} characters for easy identification in the field.

Published on 13 December 2013

\section{INTRODUCTION}

Currently, 36 species of Magnolia are known to occur in Malesia, 25 of which are endemic to the region (WCSP 2013). The family has been thoroughly studied in Malesia in comparison with many other tree families (Keng 1978, Nooteboom 1985, 1987, 1988, Kim et al. 2001). Taxonomic and phylogenetic studies using both morphological (Keng 1978, Figlar 2000, Li \& Conran 2003) and molecular data (Shi et al. 2000, Azuma et al. 2001, Kim et al. 2001, Nie et al. 2008) have challenged traditional generic concepts and relationships and modified the positions and circumscriptions of many taxa within the subfamily Magnolioideae. As a result, former segregate genera like Manglietia, Michelia and Elmerrillia have been reduced to taxa at infrageneric level in a broadened Magnolia (Figlar \& Nooteboom 2004) reflecting phylogenetic relationships. The former genus Elmerrillia Dandy, which was initially reduced to a section of the genus Magnolia by Figlar (2000), is currently treated as a subsection in Magnolia sect. Michelia (L.) Baill., based largely on its morphological characters - flowers that usually arise terminally on brachyblasts as in Michelia s.str. -, but differs slightly by its sessile gynoecium and introrse anther dehiscence. However, recently both nuclear and cpDNA sequences have shown subsect. Elmerrillia taxa to be embedded within the Michelia s.str. clade (Kim et al. 2001, Nie et al. 2008, Azuma et al. 2001) rather than forming a separate subclade. Thus, the subsectional status for this group is now in doubt.

Sulawesi is the largest island of the geologically complex insular region termed Wallacea. While levels of biodiversity and endemism are high (Myers et al. 2000), Sulawesi's flora remains poorly known and botanical collections are sparse compared to the other major Malesian islands (Frodin 2001). The results of recent intensive tree inventories for ecological studies in montane areas of Central Sulawesi have highlighted the deficiencies

\footnotetext{
1 Plant Ecology, Albrecht von Haller Institute for Plant Sciences, University of Göttingen, Untere Karspüle 2, 37073 Göttingen, Germany;

corresponding author e-mail: fabian.brambach@biologie.uni-goettingen.de.

2 Naturalis Biodiversity Center, section Botany, P.O. Box 9517, 2300 RA

Leiden, The Netherlands; e-mail: Hans.Nooteboom@naturalis.nl.

${ }^{3}$ Vegetation and Phytodiversity Analysis, Albrecht von Haller Institute for Plant Sciences, University of Göttingen, Untere Karspüle 2, 37073 Göttingen, Germany; e-mail: heike.culmsee@bio.uni-goettingen.de.
}

in the taxonomic and distribution data for Sulawesi (Culmsee \& Pitopang 2009, Berg \& Culmsee 2011, Culmsee et al. 2011). Due to their size, valuable timber and potential use as ornamentals, Magnolias are likely to be well represented in botanical collections. However, only recently Magnolia utilis (Dandy) V.S.Kumar, a species otherwise known to occur in Continental Southeast Asia and Borneo, was recorded in Sulawesi's Southeast Peninsula for the first time (Wen \& Kartonegoro 10261, 10276; BO, US). In the course of our above-mentioned tree inventory studies in montane forests of Sulawesi, we now discovered a new Magnolia species of subsect. Elmerrillia, which is - to our present knowledge - endemic to the island. Here, we describe the new species and place it in existing keys. In addition, we provide a new key to the ten known Magnolia species of Sulawesi based on vegetative characters for easy identification in the field. For the construction of the keys, in addition to our own observations and specimens from Sulawesi, herbarium specimens were studied at Herbarium Bogoriense (BO), Herbarium Celebense (CEB), Herbarium Göttingen (GOET), Royal Botanic Gardens Kew (K) and National Herbarium of the Netherlands ( $L, U)$.

\section{Magnolia sulawesiana Brambach, Noot. \& Culmsee, sp. nov.} — Fig. 1; Map 1

Prope M. tsiampacca (L.) Figlar \& Noot. et M. platyphyllam (Merr.) Figlar \& Noot. subsectionis Elmerrillia (Dandy) Figlar \& Noot. speciebus ceteris in petioli sulco superiore tantum pilis villosis plus minusve persistentibus et folii pagina inferior in lineis angustis proxime iuxta costae utrinque laterem, gynoecio 8-12 carpellis differt. - Type: Brambach et al. 1334 (flowers; holo L 3 sheets; iso BO, CEB), Indonesia, Province of Central Sulawesi (Sulawesi Tengah), Poso Regency, Lore Tengah District, Lore Lindu National Park, Mt Dali (S01.700', E120.150'), 1950 m, 23 Jan. 2012.

Evergreen trees of tropical montane rain forest, up to $35 \mathrm{~m}$ tall and $100 \mathrm{~cm}$ diam. Bark grey-brown, fissured, lenticellate, of mealy texture, flaking off in large, irregular plates on older trees, inner bark yellow, turning orange upon contact with air. Twigs monopodial, proleptic, glabrous, c. 2-3 $\mathrm{mm}$ diam in the distal internodes; slightly flattened, more so at the nodes, innovations glossy green (reddish brown when dry), soon becoming darker green (darker brown when dry), with dispersed, conspicuous white lenticels; bark on older twigs silver-grey with fine longitudinal cracks. Stipules amplexicaul, free from the 
Fig. 1 Magnolia sulawesiana Brambach, Noot. \& Culmsee. a. Leafy twig with flowers in four different development stages: flower buds (1st and 2nd to the right), open flower (middle) and young fruit after petals shed (left); b. ripe fruit (a. Brambach et al.1334, b. Brambach et al. 0109; all L).

$1 \mathrm{~cm}$

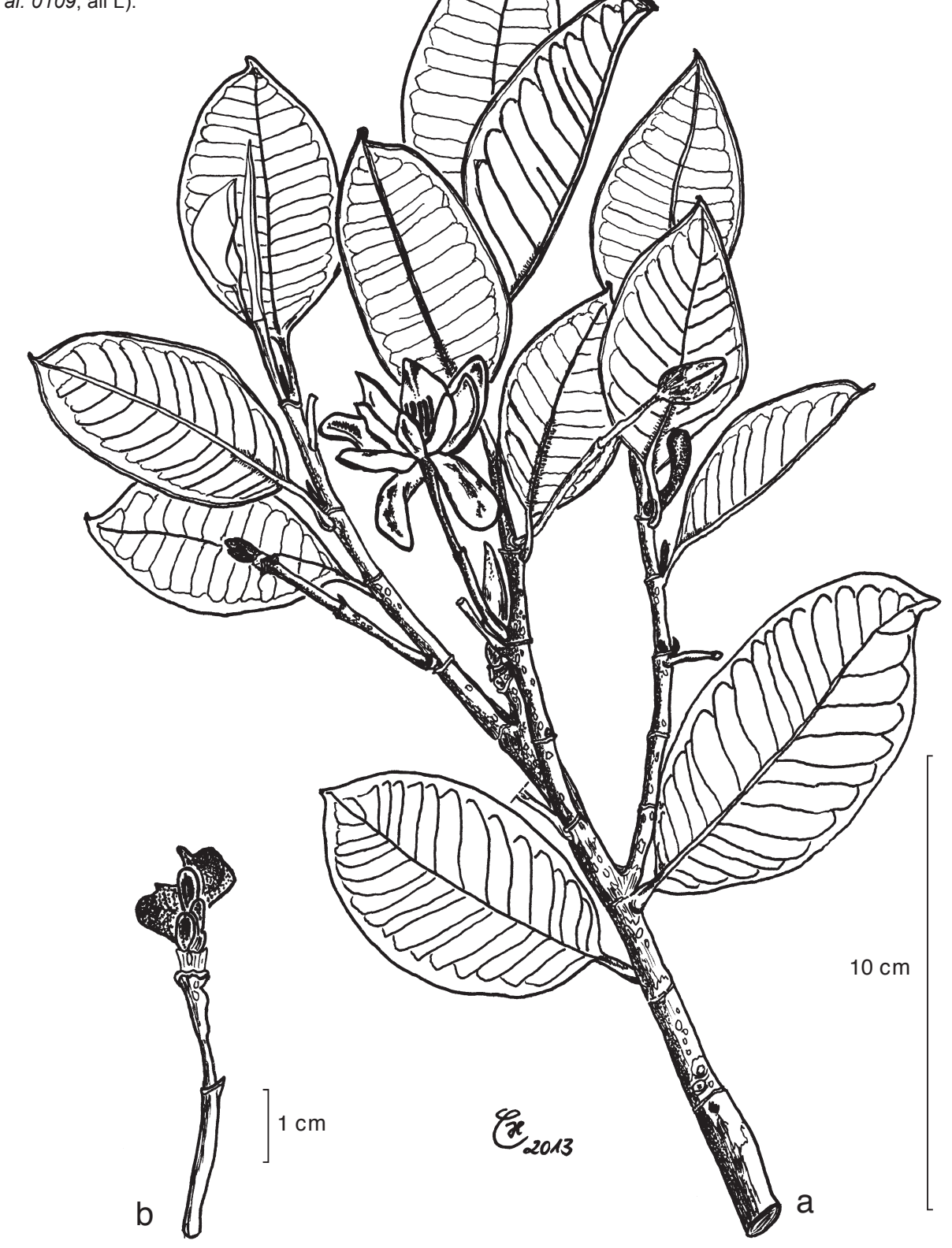

舟

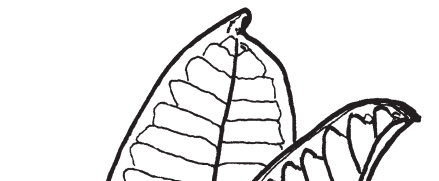

petioles, yellowish green (reddish brown when dry), glabrous, cigar-shaped, flattened and usually twisted, becoming up to $6 \mathrm{~cm}$ long, caducous, leaving white contrasting annular scars. Leaves glabrous except for a line of brown (pale when dry), erect, villous hairs running through the adaxial petiole groove to about the middle of the abaxial side of the leaf blade on both sides of the midrib, conspicuous in young leaves, glabrescent but often some hairs persistent; spirally arranged, usually oblong, elliptic or (narrowly) obovate (rarely narrowly ovate), the midrib arching downwards, V-shaped in cross section (midrib usually distorted when dry), (5-)6-9(-11) by $(2.5-) 3-4.5(-6.5) \mathrm{cm}$, ratio (1.6-)1.9-2.2(-2.4), margin entire, revolute, not thickened; base rounded to obtuse (to acute), slightly asymmetric, apex rounded to obtuse (to acute), with a short triangular, usually contorted acumen (c. 1-3 mm); coriaceous shiny green above (pale greenish brown to reddish brown when dry), paler beneath, (darker golden-brown to chestnut when dry); midrib flat and narrow above, round and strongly prominent beneath, yellowish green on both sides (concolorous with leaf blade above, chestnut and darker than leaf blade beneath when dry), running up to the very tip, there often forming a tiny, inconspicuous mucro; lateral veins (13-)15-18(-20) per side, not very conspicuous, diverging at moderate to wide angles, running straight, \pm parallel, rarely branching, intersecondary veins rarely present, irregularly looping near the margin, concolorous and slightly impressed above, the surface minutely bullate, contrasting darker green and not prominent beneath (concolorous and clearly prominent on both surfaces when dry); 3 rd order venation subscalariform to reticulate, not very distinct from the reticulate 4th order venation, colour and prominence similar to lateral veins but slightly less prominent. Petioles $(0.9-) 1.1-1.7(-2.1) \mathrm{cm}$ long, tapering towards the apex, concolorous with the young twigs, on the adaxial side a narrow groove with brown (pale when dry) hairs. Flowers bisexual, glabrous, solitary, terminal on brachyblasts. Brachyblasts sylleptic in the axils of normal foliage leaves (or leaves vestigial); 40-55 by $1-2 \mathrm{~mm}$ at anthesis, clavate, in colour and texture similar to young twigs; consisting of three internodes, the proximal two of which of \pm equal length, the distal one reduced, so the flower sessile; one spathaceous bract at each node, adnate to vestigial, inconspicuous petioles, outside concolorous with the brachyblast, withering yellowish brown and splitting in two before being shed, inside golden-brown when dry (not seen fresh). Tepals 12, free, spathulate, white (chestnut when dry), 
subequal, in two whorls: outer three similar, c. 20 by $7 \mathrm{~mm}$, inner 9 successively becoming narrower, innermost ones c. 18 by $3 \mathrm{~mm}$. Stamens c. 12, filaments c. $1 \mathrm{~mm}$ long, anthers creamyyellow (chestnut when dry), linear, bifacially flattened, arching inwards, c. $8 \mathrm{~mm}$ long, bisporangiate, introrse, opening by two longitudinal slits along their whole length, connective rounded to subacute, c. $0.5 \mathrm{~mm}$ long. Gynoecium sessile, covered by the stamens at anthesis, carpels 8-11, spirally arranged on the receptacle, \pm ovoid, fresh green with white lenticels (black when dry), the styles minutely curved outwards. Fruit irregular, $1-2.5 \mathrm{~cm}$ long, fruiting carpels concrescent in developing fruit, finally free, only $2-3$ of them developing seeds, dehiscing along the dorsal suture, falcate midrib sometimes persistent. Seeds not seen.

Distribution - Endemic to Sulawesi according to the present state of knowledge; recorded from the central part of Sulawesi (Provinces of Central Sulawesi and South Sulawesi) at elevations of 1600-2200 m. In Lore Lindu National Park it has been found at two sites, Mt Nokilalaki (at 1600 and 1900 m a.s.I.) and Mt Dali (at $1950 \mathrm{~m}$ a.s.I.). The third collection site is located in the Regency of Masamba at $2200 \mathrm{~m}$ a.s.l. (exact location unknown). The known area of distribution spans a range of $\mathrm{c}$. $100 \mathrm{~km}$ in $\mathrm{N}-\mathrm{S}$ direction.

Ecology - Large, canopy forming trees of primary, everwet, montane forests growing on gently sloping ridges over granite-derived soils. At Mt Nokilalaki (1900 m a.s.I.), M. sulawesiana is co-dominant in a Fagaceae and Myrtaceae forest. At Mt Dali, it occurs together with M. carsonii Dandy ex Noot. var. carsonii (see below for discussion of infraspecific taxonomy) and M. liliifera (L.) Baill. var. liliifera in a forest dominated by Fagaceae, Myrtaceae and conifers. Flowering was observed in January, March and August; fruiting in March.

Conservation status - The three collection localities of the species all lie within the mountain range of the central part of Sulawesi. Since the area is little explored botanically, and $M$. sulawesiana can be locally abundant (see Ecology), we expect the species to occur more widely within the mountain range. The land area of Sulawesi lying above $1500 \mathrm{~m}$ a.s.l. is c. $13600 \mathrm{~km}^{2}$ (calculated in Quantum GIS Version 1.8.0 using SRTM data from Jarvis et al. 2008). Forest condition in these upland areas is so far mostly good to old-growth (Cannon et al. 2007), but pressure on the montane forests has increased during recent years where access was possible and is expected to intensify further. Based on these indications we propose a preliminary conservation assessment of Near Threatened (NT).

Additional specimens. INDONESIA, Province of Central Sulawesi (Sulawesi Tengah), Poso Regency, Lore Tengah District, Lore Lindu National Park, Mt Dali (S01.700 , E120.150), 1950 m, 27-31 Mar. 2011, Brambach et al. 0109 (from same tree as type, flower buds and fruits; BO 2 sheets, CEB 2, GOET 2, K 2, L 2); Province of Central Sulawesi (Sulawesi Tengah), Sigi Regency, Nokilalaki District; Lore Lindu National Park, Mt Nokilalaki $\left(\mathrm{S} 01.243^{\circ}, \mathrm{E} 120.153^{\circ}\right), 1900 \mathrm{~m}$, Aug. 2007, Culmsee 2581 (flower buds and young fruits; CEB 2, GOET, L), Culmsee 2945 (sterile; CEB, GOET), Culmsee 3153 (sterile; GOET), Culmsee 3154 (sterile; L); Province of South Sulawesi (Sulawesi Selatan), Masamba Regency, Boschafdeeling Salotoradja, \pm 2200 m, 21 Oct. 1937, Netherland Indies Forest Service (NIFS) bb 23355 (sterile; BO, L); Province of Central Sulawesi (Sulawesi Tengah), Sigi Regency, Nokilalaki District, Lore Lindu National Park, Mt Nokilalaki, 1600 m, Apr.-May 2008, Sabir et al. B2 109 (sterile; CEB).

Notes - Magnolia sulawesiana belongs to subsect. Elmerrillia and is morphologically most similar to $M$. tsiampacca var. tsiampacca and $M$. platyphylla from that subsection. It differs from both species by its far fewer carpels (8-11 vs $>20)$. It can also be distinguished from the sympatric $M$. tsiampacca var. tsiampacca by its usually smaller, oblong leaves which, as the rest of the tree, are completely glabrous except for the distinctive line of hairs that starts in the groove on the upper petiole side and continues on the lower surface of the leaf

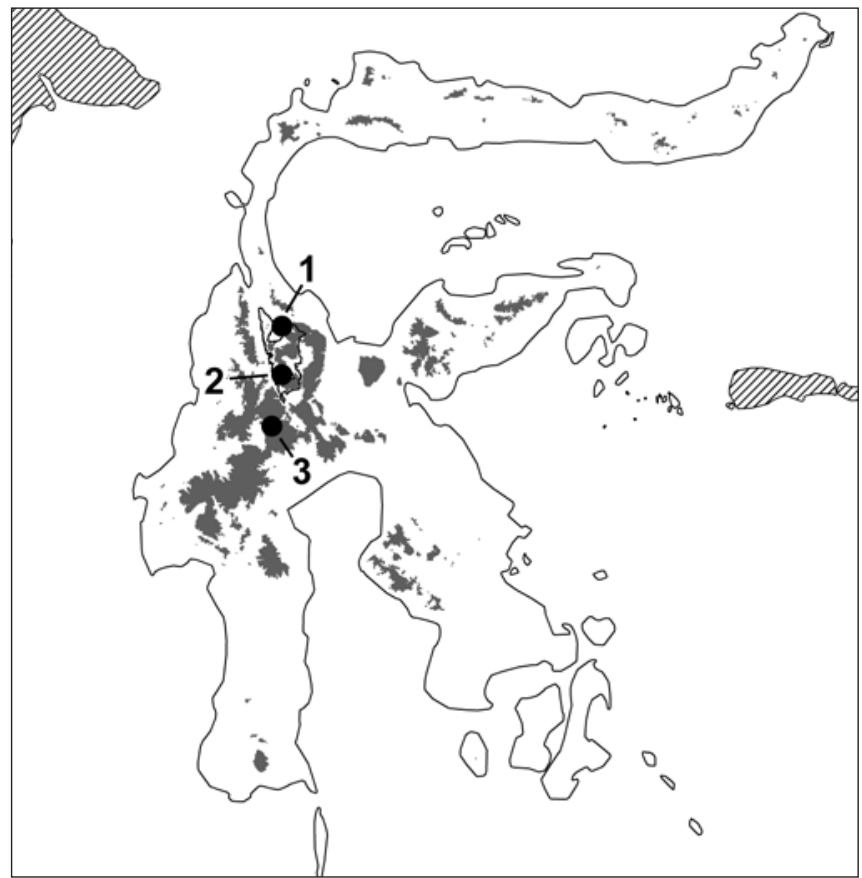

Map 1 Map of the known occurrences of Magnolia sulawesiana Brambach, Noot. \& Culmsee in the central part of Sulawesi. 1. Culmsee 2581, 2945, 3153,$3154 ;$ 2. Brambach et al. 0109, 1334; 3. NIFS bb 23355 (approximate location). Collection sites 1 and 2 are located within Lore Lindu National Park (bold black line). Grey areas indicate montane elevations $\geq 1500 \mathrm{~m}$ a.s.l.

blade along a narrow line on each side of the midrib. The leaves of $M$. platyphylla are completely glabrous, much larger and do not have the close reticulation of $M$. sulawesiana. The species is also superficially similar to $M$. carsonii Dandy ex Noot. var. drymifolia Noot. of subsect. Maingola because of its small, coriaceous, densely reticulate leaves. The former can be distinguished from the latter by the flowers with narrow white tepals on axillary brachyblasts (vs terminal flowers with oblong tepals, the outer ones green, the inner ones yellow), its almost complete glabrousness, and the leaves with green lower surfaces (vs glaucous) and more numerous lateral veins (13-20 vs 6-12).

The sterile specimen NIFS bb 23355 (see Additional specimens) was the only known record of $M$. carsonii var. drymifolia from Sulawesi. However, it is clearly a representative of $M$. sulawesiana. The distribution of the former taxon thus now remains restricted to Thailand, Sumatra, Borneo and possibly the Philippines (Palawan).

The name Magnolia vrieseana from inventory plot Nokilalaki (N1), published by Culmsee et al. (2011, Appendix species no. 33) is hereby corrected to Magnolia sulawesiana.

\section{KEYS TO SPECIES OF MAGNOLIA SUBSECTION ELMERRILLIA (SECTION MICHELIA)}

The species can be accommodated in the key of Nooteboom (1988). Names were adapted according to Figlar \& Nooteboom (2004).

\section{Key based on characters of flowers and fruits}

1. Tepals 12. Carpels concrescent during development, becoming free at dehiscence . . . . . . . . . . . . . 2

1. Tepals (12-)17. Carpels concrescent during development, remaining that way, forming a syncarp or becoming free at dehiscence ............... 4

2. Twigs and stipules hairy $\ldots \ldots \ldots \ldots$. . . tsiampacca

2. Twigs and stipules glabrous $\ldots \ldots \ldots \ldots \ldots \ldots$ 
3. Leaves large (>20 cm long). Carpels $>20$. Plant completely glabrous. - Philippines ............. M. platyphylla

3. Leaves small ( $<12 \mathrm{~cm}$ long). Carpels $<12$. Plants with hairs in the adaxial petiole grooves and next to the midrib on the lower leaf surfaces. - Sulawesi ......... M. sulawesiana

4. Undersurface of leaves glaucous (sometimes a dense indumentum of adpressed hairs obscuring the glaucousness), hairy (in New Guinea sometimes glabrous: var. glaberrima). Fruiting carpels free, dorsally dehiscing. - Borneo, Sulawesi, Maluku, New Guinea . . . . . . . . M. tsiampacca

4. Undersurface of leaves not glaucous, glabrous or hairy. Fruiting carpels concrescent . . . . . . . . . 5

5. Twigs glabrous or yellowish villous, \pm soon glabrescent, rarely pubescent. Nerves in (10-)14-21 pairs. - Sulawesi, Maluku . . . . . . . . . . . . . . . . . . vrieseana

5. Twigs densely fulvously pubescent or tomentose, later glabrescent. Nerves in 20-24 pairs. - Philippines (Mindanao) ...................... pubescens

\section{Key based on fruit characters}

1. Carpels thickly concrescent, forming a syncarp, ripe carpels shedding their apical parts. . . . . . . . . . . 2

1. Carpels thinly concrescent, becoming free when ripe and longitudinally dehiscing $\ldots \ldots \ldots \ldots \ldots$

2. Young twigs and stipules glabrous or yellowish villous, \pm soon glabrescent, rarely pubescent. Nerves in (10-)14-21 pairs. - Sulawesi, Maluku .............. vrieseana

2. Twigs densely fulvously pubescent or tomentose, later glabrescent. Nerves in 20-24 pairs. - Philippines (Mindanao) ........................ pubescens

3. Carpels $<12$. Sulawesi . . . . . . . . . sulawesiana

3. Carpels $>20 \ldots \ldots \ldots \ldots \ldots \ldots \ldots$

4. Twigs and leaves glabrous. Brachyblast glabrous. - Philippines ..................... platyphylla

4. Twigs and leaves glabrous or hairy. Brachyblast hairy (except rarely in New Guinea: var. glaberrima). - Borneo, Sulawesi, Maluku, New Guinea . . . . . . . . . . . . M. tsiampacca

\section{Key to the species of Magnolia occurring in Sulawesi}

The following key does not differentiate between the two varieties of M. carsonii found in Sulawesi, M. carsonii var. carsonii and M. carsonii var. phaulanta (Dandy ex Noot.) S.Kim \& Noot. As Nooteboom (1988) already pointed out, the two are very similar, possibly conspecific, and can only be differentiated by quantitative characters. The difference in leaf size (Kim et al. 2002) could not be confirmed for specimens from Sulawesi and Borneo present in the collections in $\mathrm{L}$ and $\mathrm{BO}$, leaving slight differences in flower size (cluster of perianth and stamen scars 2-3 $\mathrm{mm}$ vs c. $1 \mathrm{~mm}$ long) as the only separating character. We therefore prefer to treat all collections from Sulawesi as M. carsonii var. carsonii.

Within Sulawesi and its satellite islands $M$. angatensis is only known from one sterile collection on Talaud Island (Lam 3121 , L), midway between the north-eastern tip of Sulawesi and the Philippine island of Mindanao. Distinction between the many forms of $M$. liliifera and $M$. angatensis based on sterile material is nearly impossible. We do not treat the latter species separately in the key, because it would key out together with M. liliifera.

The key is mostly based on vegetative characters for easy identification in the field. Information on distribution (geography and elevation) is based on available material (from BO, CEB, GOET, $\mathrm{K}, \mathrm{L}$ and $\mathrm{U}$ ). All species known to occur on the island of Sulawesi and surrounding minor islands (e.g. Kabaena, Buton, Sangihe and Talaud) as defined in Brummitt (2001) are included. It is intended to work for specimens from Sulawesi and may not cover intraspecific variation found on other Malesian islands. Leaf measurements are given for mature trees unless indicated otherwise; young trees and adventitious shoots may have larger leaves.

See the Identification List for complete binomials with author names.

1. Stipules adnate to the petiole. In older or fallen leaves visible by a scar on the upper side of the petiole . . . . . . 2

1. Stipules free. Petioles without a scar on the upper side . 6

2. Young twigs, stipules and peduncles glabrous or with minute adpressed hairs (hardly visible with a handlens). Stipule scar up to half the petiole length. Flowers terminal on leafy twigs

2. Young twigs, stipules and peduncles usually conspicuously hairy (sometimes glabrous or glabrescent). Stipule scar about half to the full length of the petiole. Flowers terminal on leafy twigs or on axillary short shoots . . . . . . . . 4

3. Stipule scar up to one third the petiole length (rarely up to half the length). Fruits ellipsoid or ovoid, only slightly longer than wide. Carpels opening first along the ventral suture. - Widespread, 1000-1500 m.

M. sumatrana var. glauca

3. Stipule scar one third to half the petiole length. Fruits cylindrical, 2-3 times as long as broad. Carpels opening first along the dorsal suture. - C and SE Sulawesi, rare, 800-1200 m

M. utilis

4. Leaves c. 9-22 cm long, lanceolate, the widest part of the blade always beneath the middle. Petiole base not or only slightly thickened. Young twigs with numerous conspicuous white lenticels. Branching monopodial, internodes evenly spaced, flowers terminal on axillary short shoots. Cultivated, 0-1000 m . . . . . . . . . . . champaca var. champaca

4. Leaves c. 9-42 cm long, narrowly elliptic to elliptic (to oblanceolate), the widest part of the blade close to the middle or above it. Young twigs with few, dark, or no lenticels. Branching sympodial, internodes often conspicuously varying in length along twigs. Flowers terminal on normal leafy twigs. Occurring naturally, $0-2000 \mathrm{~m} \mathrm{..........} 5$

5. Young twigs, stipules and underside of leaf blades woolly hairy, the hairs curled like pigs' tails, coming off in patches, usually \pm persistent on midrib and lateral veins of leaf undersurfaces. - N peninsula of Sulawesi, once recorded at $150 \mathrm{~m}$

M. villosa

5. Young twigs, stipules and underside of leaf blades glabrous or silky hairy, the hairs, if present, adpressed and straight (sometimes mixed with minute curled hairs), persistent or not. - Widespread and variable, 0-2000 m.

M. liliifera var. liliifera

6. Young twigs and outside of stipules hairy (or twigs glabrous, but then stipules at least hairy outside at the very tip). Most leaves $>15 \mathrm{~cm}$ long. Carpels $>40$ per flower. - Widespread and common, $0-1300 \mathrm{~m} \ldots \ldots \ldots \ldots \ldots \ldots$

6. Young twigs and outside of stipules completely glabrous. Most leaves 3-12 cm long. Carpels $<20$ per flower. - Central part of Sulawesi, $750-2200 \mathrm{~m} \ldots \ldots \ldots . . .8$

7. Leaves narrowly oblong, narrowly ovate or lanceolate (index 2.2-4.2). Leaf undersurface glaucous, densely adpressed hairy (sometimes hairs very small and hardly visible with a handlens). Young twigs and stipules usually with short ( $\leq 1 \mathrm{~mm}$ long), adpressed hairs. Mature fruits with free carpels, each carpel opening by a longitudinal slit. - 0-1300 m

M. tsiampacca var. tsiampacca 
7. Leaves (ob)ovate to elliptic (index 1.7-2.3, in juveniles often oblanceolate). Leaf undersurface not glaucous, glabrous, with scattered short hairs, or with long, curled hairs. Young twigs and stipules glabrous except for the stipule tip or with long (c. $2 \mathrm{~mm}$ ), yellow hairs. Mature fruits with carpels united, the outer parts breaking off in irregular masses. - 0-1100 m

M. vrieseana

8. Leaves completely glabrous, chartaceous to thin-coriaceous, lateral veins 8-15 per side. Young twigs with few or no lenticels. Flowers terminal on leafy twigs, appearing leaf-opposed due to sympodial vegetative growth. - 1200-2000 m . .

M. carsonii var. carsonii

8. Leaves with a line of hairs in the adaxial petiole groove and on the leaf undersurface on both sides of the midrib (hairs lost in older leaves), otherwise glabrous, coriaceous, lateral veins $13-20$ per side. Young twigs conspicuously lenticellate. Flowers on axillary brachyblasts (rarely terminal). $-1600-2200 \mathrm{~m}$. . . . . . . . . . . . M. sulawesiana

Acknowledgements This research was supported by the German Research Foundation (DFG), grant CU127/3-1, and a PhD scholarship of Evangelisches Studienwerk e.V., Villigst (Germany). The authors would like to thank Hardianto Mangopo, Firdaus, Rickson Tiranda and Matthias Faber for their valuable help during the collection of the type specimen. We are indebted to Aiyen Tjoa (Tadulako University, Palu, Indonesia), Balai Besar Taman Nasional Lore Lindu (Palu, Indonesia) and LIPI (Bogor, Indonesia) for support during fieldwork. Jan-Frits Veldkamp helped with the Latin diagnosis, which is gratefully acknowledged. We would like to thank an anonymous reviewer for constructive comments to improve our manuscript.

\section{REFERENCES}

Azuma H, García-Franco JG, Rico-Gray V, Thien LB. 2001. Molecular phylogeny of the Magnoliaceae: The biogeography of tropical and temperate disjunctions. American Journal of Botany 88, 12: 2275-2285.

Baillon H. 1868. Magnoliaceae. Histoire des Plantes 1: 133-161.

Berg CC, Culmsee H. 2011. Ficus schwarzii redefined and two new species of Ficus (Moraceae) from Sulawesi (Indonesia) described. Blumea 56: $265-269$

Blanco FM. 1837. Flora de Filipinas: Segun el sistema sexual de Linneo. Manila.

Brummitt RK. 2001. World geographical scheme for recording plant distributions, ed. 2, Plant taxonomic database standards No. 2. International Working Group on Taxonomic Databases for Plant Sciences (TDWG). York, UK. Cannon CH, Summers M, Harting JR, Kessler PJA. 2007. Developing conservation priorities based on forest type, condition, and threats in a poorly known ecoregion: Sulawesi, Indonesia. Biotropica 39: 747-759.

Culmsee H, Pitopang R. 2009. Tree diversity in sub-montane and lower montane primary rain forests in Central Sulawesi. Blumea 54: 119-123. Culmsee H, Pitopang R, Mangopo H, Sabir S. 2011. Tree diversity and phytogeographical patterns of tropical high mountain rain forests in Central Sulawesi, Indonesia. Biodiversity and Conservation 20: 1103-1123.

Figlar RB. 2000. Proleptic branch initiation in Michelia and Magnolia subgenus Yulania provides basis for combinations in subfamily Magnolioideae. In: Liu YH, Fan HM, Chen ZY, Wy QG, Zeng QW (eds), Proceedings of the International Symposium on the family Magnoliaceae, May 18-22, 1998, Guangzhou, China: 14-25. Science Press.

Figlar RB, Nooteboom HP. 2004. Notes on Magnoliaceae IV. Blumea 49: 87-100.

Frodin D. 2001. Floras in retrospect and for the future. Plant Talk 25: 36-39. Jarvis A, Reuter HI, Nelson A, Guevara E. 2008. Hole-filled seamless SRTM data V4, International Centre for Tropical Agriculture (CIAT). Published on the Internet; http://srtm.csi.cgiar.org. Last accessed 26 Mar. 2013.

$\mathrm{Keng} \mathrm{H.} \mathrm{1978.} \mathrm{The} \mathrm{delimitation} \mathrm{of} \mathrm{the} \mathrm{genus} \mathrm{Magnolia} \mathrm{(Magnoliaceae).} \mathrm{The}$ Garden's Bulletin Singapore 31: 127-131.

Kim S, Park CW, Kim YD, Suh Y. 2001. Phylogenetic relationships in family Magnoliaceae inferred from ndhF sequences. American Journal of Botany 88, 4: 717-728

Kim S, Nooteboom HP, Park CW, Suh Y. 2002. Taxonomic revision of Magnolia section Maingola (Magnoliaceae). Blumea 47: 319-339.

Li J, Conran JG. 2003. Phylogenetic relationships in Magnoliaceae subfam. Magnolioideae: a morphological cladistics analysis. Plant Systematics and Evolution 242: 33-47.
Linnaeus C. 1753. Species plantarum. Holmiae, Impensis laurentii salvii. Myers N, Mittermeier RA, Mittermeier CG, Da Fonseca GAB, Kent J. 2000. Biodiversity hotspots for conservation priorities. Nature 403: 853-858.

Nie ZL, Wen J, Azuma H, Qiu YL, Sun H, Meng Y, Sun WB, Zimmer EA. 2008. Phylogenetic and biogeographic complexity of Magnoliaceae in the Northern Hemisphere inferred from three nuclear data sets. Molecular Phylogenetics and Evolution 48: 1027-1040.

Nooteboom HP. 1985. Notes on Magnoliaceae. With a revision of Pachylarnax and Elmerrillia and the Malesian species of Manglietia and Michelia. Blumea 31: 65-121.

Nooteboom HP. 1987. Notes on Magnoliaceae II. Revision of Magnolia sections Maingola (Malesian species), Aromadendron and Blumiana. Blumea 32: $342-382$

Nooteboom HP. 1988. Magnoliaceae. Flora Malesiana, Ser. I, 10, 3: 561-605. Pierre JBL. 1880. Flore Forestiere de la Cochinchine. Paris.

Shi S, Jin H, Zhong Y, He X, Huang Y, Tan F. 2000. Phylogenetic relationships of the Magnoliaceae inferred from cpDNA matK sequences. Theoretical and Applied Genetics 101: 925-930.

WCSP. 2013. World Checklist of Selected Plant Families. Facilitated by the Royal Botanic Gardens, Kew. Published on the internet: http://apps.kew. org/wcsp/. Last accessed 25 July 2013.

\section{IDENTIFICATION LIST}

Numbers in the list of examined specimens for the construction of the Sulawesi-key refer to the following species:

1. M. angatensis Blanco

2. M. carsonii Dandy ex Noot. var. carsonii

3. M. champaca (L.) Baill. ex Pierre var. champaca

4. M. liliifera (L.) Baill. var. liliifera

5. M. sulawesiana Brambach, Noot. \& Culmsee

6. M. sumatrana (Miq.) Figlar \& Noot. var. glauca (Blume) Figlar \& Noot.

7. M. tsiampacca (L.) Figlar. \& Noot. var. tsiampacca

8. M. utilis (Dandy) V.S.Kumar

9. M. villosa (Miq.) H.Keng

10. M. vrieseana (Miq.) Baill. ex Pierre

Afriastini 2112: 10; 2881: 4 - Alston 15937: 10; 16539: 7 - Anonymous s.n. (K Acc No H590 / 81 3): 7; s.n. (barcode L0450378): 7; IV F.38 (cultivated in Hortus Bogoriensis, Bogor Acc No BO-1330147, BO-1330148, BO-1330151, K Acc No. H1660/97 90): 10; s.n. (Bogor Acc No 1324097, BO-1743441, BO 1743443): 7.

Bish 123 (= NIFS bb 18128): 10; 254 (= NIFS bb 21987): 7 - Bloembergen 201 (= NIFS bb 28241): 7; 288 (= NIFS bb 28268): 2 - Brambach et al. 0047: 2; 0086: 4; 0109: 5; 0136: 2; 0145: 4; 0149: 2; 0444: 10; 0632: 10; 0662: 10; 0666: 10; 0892: 4; 1113: 7; 1334: 5; 1512: 2; 1519: 2; 1531: 4; 1554: 4; 1584: 2; 1589: 2 - Bünnemeijer 11567: 4; 12581: 3 - Burki 53 (= NIFS bb 24079): 4; 92 (= NIFS bb 24169): 7 ; 95 (= NIFS bb 24172): 2; 139 (= NIFS bb 26276): 2 - Burley et al. 3576: 4; 3618: 10; 3837: 4; 3864: 4; 3930: 10; 4080: 9.

Culmsee 39: 4; 191: 4; 975: 4; 2581: 5; 2945: 5; 3153: 5; 3154: 5; D2-2: 7; r2196: 4

De Vogel 2531: 4; 5176: 4; 6052: 4 - De Vogel \& Vermeulen 6619: 4; 6726: 4; 6811: 10; 6054: 10; 7054: 10; 7064: 10 - De Vriese \& Teijsmann 131: 3; s.n. (KAcc No H531/77 39): 6; s.n. (KAcc No H531/81 4): 7; s.n. (barcode L0038297): 4; s.n. (barcode L0038327): 10; s.n. (barcode L0450311): 6; s.n. (barcode L0450314): 6; s.n. (barcode L0450327): 10; s.n. (barcode L0450328): 10; s.n. (barcode L0450332): 10; s.n. (barcode L0450354): 10; s.n. (barcode L0450357): 7; s.n. (barcode L0450358): 7; s.n. (barcode L0450359): 7; s.n. (barcode L0450360): 7; s.n. (barcode L0450367): 7; s.n. (barcode L0450381): 4; s.n. (barcode L0450382): 4; s.n. (U Acc No 000184): 7; s.n. (U Acc No 000185): 7; s.n. (U Acc No 000200): 4; s.n. (U Acc No 000220); s.n. (BO Acc No BO-1324098): 4; s.n. (BO Acc No BO-1364647): 7.

Forman 202: 10 - Forsten 355: 4; s.n. (barcode L0038296): 10; s.n. (barcode L0450299): 4; s.n. (barcode L0450301): 4; s.n. (barcode L0450333): 10; s.n. (U Acc No 000219): 10; s.n. (BO Acc No BO-1364650): 4.

Ganggrijp 21 (= NIFS Cel./II-420): 4.

Halidjeng $11 \mathrm{H}$ (= NIFS bb 20908): 6 - Hoornstra 54 (= NIFS bb 13487): 10 Irot 4 (= NIFS bb 26296): $2 ; 12$ (= NIFS bb 26637): 2 .

Kamang 1 (= NIFS bb 31912): 4 - Kessler et al. PK 3008: 10; PK 3009: 4 -Kjellberg 1839: 4 - Koorders 17768: 10; 17769: 10; 17770: 7; 17771: 7; 17772: 7; 17773: 7; 17774: 7; 17775: 7; 17776: 7; 17777: 7; 17778: 7; 17779: 10; 17782: 10; 17783: 4; 17784: 4; 17785: 4; 17787: 10; 17788: 10; 17789: 10; 17790: 10; 17791: 4; 17792: 4; 17793: 10; 17794: 4; 17795: 4; 17796: 4; 17797: 10; 24081: 10. 
Lam 2430: 10; 3121: 1 - Linggi 1 (= NIFS bb 32803): 7 - Luntungan 1 (= NIFS bb 20000): 7 .

McDonald \& Ismail 3874: 4 - Meijer 9360: 4; 9584: 10; 9611: 10; 9628: 10; 9726: 10; 9811: 7; 10010: 8; 10016: 7; 10080: 10; 11006: 7 - Moningka 1 (= NIFS bb 19979): 10; 2 (= NIFS bb 19980): 10 .

Netherland Indies Forest Service (NIFS) bb 12385 (= Warouw 1): 4; bb 12386: 10; bb 13487 (= Hoornstra 54): 10; bb 13512 (= Wullur 11): 10; bb 14217 (= Wullur 55): 4; bb 15701 (= Soekarman 12): 10; bb 17121 (Roringpandej 22): 10; bb 18128 (= Bish 123): 10; bb 18195: 2; bb 19581 (= Waturandang E 65): 2; bb 19605 (=Verhoef 121): 4; bb 19703: 6; bb 19726 (=Tumbel 1): 7; bb 19576 (= Waturandang E 60): 7; bb 19979 (= Mongingka 1): 10; bb 19980 (= Moningka 2): 10; bb 20000 (= Luntungan 1): 7; bb 20200 (= von Werner 3): 10; bb 20908 (= Halidjeng $11 \mathrm{H}$ ): 6; bb 21615 (= Waturandang 178): 10; bb 21987 (= Bish 254): 7; bb 21988 (= Patabang 1): 7; bb 21989 (= Patabang 2): 7; bb 23355: 5; bb 24079 (= Burki 53): 4; bb 24169 (= Burki 92): 7; bb 24172 (= Burki 95): 2; bb 24510 (= Rantegaoe E 296): 10; bb 26276: 2; bb 26296 (= Irot 4): 2; bb 26637 (= Irot 12): 2; bb 28241 (= Bloembergen 201): 7; bb 28268 (= Bloembergen 228): 2; bb 28295 (= Silo 4): 3; bb 29194 (= Togas 22): 2; bb 31815 (= Pello 1): 10; bb 31863 (= Politon 38): 10; bb 32323 (= Rantegaoe 19): 10; bb 32459 (= Reppie 19): 10; bb 32472 (= Politon 76): 10; bb 32567 (= Polei 1): 7; bb 32568 (= Polei 2): 4; bb 32803 (= Linggi 1): 7; bb 33115 (= Tangkilisan 1): 7; Cel./II-201 (= Waturandang 640): 4; Cel./II-420 (= Ganggrijp 21): 4; Cel./III-8 (= Waturandang 8, 55, 158): 10; Cel./III-100 (= Reppie 300): 10; Cel./III-101 (= Reppie 301): 10; Cel./III-102 (= Reppie 302):11; Cel./V-308 (= Reppie 527): 10 - Niswan 85: 7 - Noerkas 257: 4; 467: 10.
Patabang 1 (= NIFS bb 21988): $7 ; 2$ (= NIFS bb 21989): 7 - Pello 1 (= NIFS bb 31815): 10 - Pitopang et al. RP 347: 6; RP 359: 10; RP 1005: 4 - Polei 1 (= bb 32567): 7; 2 (= bb 32568): 4; bb 24079: 4; bb 31912 (=Kamang 1): 4 - Politon 38 (= NIFS bb 31863): 10; 76 (= NIFS bb 32472): 10 - Prawioratmodjo \& Maskuri 1310: 4 - Prawioratmodjo \& Soewoko 1707: 4; 1961: 4. Rachmat 266: 3 - Ramlanto 227: 4 - Rantegaoe E 296 (= NIFS bb 24510): 10; 19 (= NIFS bb 32323): 10 - Reppie 19 (= NIFS bb 32459): 10; 300 (= NIFS Cel./III-100): 10; 301 (= NIFS Cel./III-101): 10; 302 (= NIFS Cel./III102): 10; 527 (= NIFS Cel./V-308): 10 - Riedel s.n. (K Acc No H4479/64 65): 4 - Roringpandej 22 (= NIFS bb 17121): 10.

Sabir et al. 174 N: 4; B2 109: 5 - Sands 270: 4 - Silo 4 (= NIFS bb 28295): 2 - Soekarman 12 (= NIFS bb 15701): 10.

Tangkilisan 1 (= NIFS bb 33115): 7 - Tantra 1509: 10; 1546: 4; 1603: 4; 1766 : 4 - Teijsmann 5325 HB: 7; 5781 HB: 4 - Togas 22 (= NIFS bb 29194): 2 - Tumbel 1 (= NIFS bb 19726): 7.

Van Balgooy 3430: 10 - Verhoef 121 (= NIFS bb 19605): 4 - Von Werner 3 (= NIFS bb 20200): 10 .

Warouw 1 (= NIFS bb 12385): 4 - Waturandang E 60 (= NIFS bb 19576): 7; E 65 (= NIFS bb 19581): 2; 8 (= NIFS Cel./III-8): 10; 55 (= NIFS Cel./III-8): 10; 158 (= NIFS Cel./III-8): 10;178 (= NIFS bb 21615): 10; 640 (= NIFS Cel./II-201): 4 - Webb et al. s.n. (CEB Acc No 0000707): 10 - Weber s.n. (barcode L0450316): 3 - Wen \& Kartonegoro 10261: 8; 10276: 8; 10288: 10 - Whitmore \& Sidiyasa TCW 3398: 4 - Widjaja EAW 182: 7; EAW 9619: 10 - Wullur 11 (= NIFS bb 13512): 10; 55 (= NIFS bb 14217): 4. Yusuf \& Wahyono 166: 10. 